\section{Gyulyev N., Prasolenko 0., Litomin E., Zinchenko D.}

\title{
STUDY OF THE INFLUENCE OF ROAD CONGESTION ON THE FATIGUE LEVEL OF A SANGUINE DRIVER
}

Об’єктом дослідження є процес трудової діяльності водія на міських дорогах в транспортній системі міста під час перевезення вантажів і пасажирів. Досліджено вплив дорожніх заторів на функціональний стан водія-сангвініка, що є одним з найпоширеніших типів темпераменту. Основна гіпотеза дослідження полягає в тому, що рівень втоми водія в дорожньому заторі, який впливає на час реакиї водія і на безпеку дорожнього руху, залежить від стану водія і параметрів затору. Рівень втоми водія визначається, виходячи з кониепиї про серцево-судинну систему, як індикатора адаптачійно-пристосувальної діяльності організму шляхом вимірювання електрокардіограми. При цьому аналізується нерівномірність кардіоінтервалів, що є універсальною реакцією на будь-які види навантаження. Рівень втоми обчислюється в умовних одиницях за спеціальним алгоритмом, що враховує статистичні показники, показники гістограми та дані спектрального аналізу кардіоінтервалів. За допомогою нелінійної моделі зміни функціонального стану водія-сангвініка отримані закономірності зміни рівня його стомлення при різних умовах перебування в транспортному заторі. Виявлено, що найбільш значущим чинником, який впливає на кінцевий рівень втоми водія в заторі, $\epsilon$ його початкове значення перед затором. Другим за важливістю параметром, що впливає на зміну рівня втоми водія-сангвініка, є тривалість транспортного затору, яка впливає на вихідну функцію тільки спільно з початковим рівнем втоми. Вплив віку водія-сангвініка на рівень втоми в заторі проявилося в меншій мірі. Однак умови перебування в дорожньому заторі найбільш відчутно впливають на водїв більш старшого віку (шістдесят і більше років) в порівнянні з молодими водіями двадияти років. Аналіз результатів досліджень показав, що затори тривалістю понад дванадиять хвилин призводять до значного зростання рівня втоми водія-сангвініка. Це може привести до підвищення ймовірності скоєння дорожньо-транспортної пригоди. Тенденщї змінювання рівня втоми водія-сангвініка в заторі, виявлені в ході дослідження, дозволяють прогнозувати поведінку водія після виходу з дорожнього затору і оцінити можливі схеми розвитку дорожньо-транспортної ситуації, які безпосередньо впливають на безпеку дорожнього руху.

Ключові слова: дорожній затор, рівень втоми, темперамент, водій-сангвінік, безпека дорожнього руху.

Received date: 23.10 .2019

Accepted date: 12.11.2019

Published date: 30.12.2019
Copyright (C) 2019, Gyulyev N., Prasolenko O., Litomin E., Zinchenko D. This is an open access article under the CC BY license (http://creativecommons.org/licenses/by/4.0)

\section{Introduction}

Outpacing the growth rate of the level of motorization compared with the development of the street-road network of modern cities lead to the formation of queues and congestion at intersections and sections of roads. Staying in traffic congestion imposes certain restrictions on the driver in its activity. Traffic congestion not only reduces the speed of movement of drivers and passengers, the movement of goods, worsens the ecological condition of the city, but also negatively affects the psychophysiology of the driver, worsening its functional condition [1].

The concept of «functional state» characterizes the effective sphere of human activity. A change in the functional state of the driver affects the fatigue degree and, as a consequence, the safety of movement [2].

In [1], the author investigated the influence of working conditions, personal qualities of the driver and its psychophysiological state on the reliability of work. The most significant factors affecting the dynamics of fatigue development are the intensity of movement and monotonous working conditions. It is found that the reliability of the driver depends on the level of its emotional stress. As a stress level meter selected heart rate. And in [3], the effect of traffic congestion on the psycho-vegetative status of public transport drivers is analyzed, taking into account the age and length of service. These studies are conducted using questionnaires by means of a survey. In [4], the negative role of traffic congestion is emphasized and the mechanism of traffic congestions in the urban road network is investigated. In [5], for the first time, the problem of choosing a function for predicting traffic congestions is investigated. A new method is proposed for estimating the probability of traffic congestions for solving multidimensional calculations for many one-dimensional possibilities and their combinations. However, in all the other works mentioned, the effect of traffic congestions on the level of driver fatigue is not investigated. So, in [6], the relationship between traffic congestions and mood, as well as driver behavior, is investigated. And in $[7,8]$ methods of dealing with traffic congestions are proposed. But they also do not study the issues of changing the state of drivers.

The authors of [9] note that the problem of traffic congestions on city roads is very relevant, therefore, they 
considered the formation of congestion, especially on city roads, where the driver's reaction time also affects the size of traffic congestions. In [10], the negative role of traffic congestion is noted. A model of driver behavior is considered, which allows predicting the appearance of traffic congestions. However, how traffic congestions affect the driver's condition and its fatigue level are not considered in these works.

Thus, the study of changes in the fatigue level of a sanguine driver in traffic congestions is relevant. Therefore, the object of research is the process of the driver's labor activity on city roads in the city's transport system when transporting goods and passengers. And the aim of research is determination of the patterns of change in the fatigue level of a sanguine driver in traffic congestions.

\section{Methods of research}

The study of the effect of traffic congestion on the fatigue level of a sanguine driver consists in recording the electrocardiogram of drivers at the entrance to the traffic congestion, in the traffic congestion itself and when exiting it.

The fatigue level of a sanguine driver is calculated in arbitrary units according to R. Baevsky according to a special algorithm that takes into account statistical indicators, histogram indicators and data of spectral analysis of cardio intervals. The fatigue level allows to differentiate different degrees of tension of regulatory systems and assess the adaptive capabilities of the body [11]. It is calculated according to an algorithm that takes into account five criteria:

$$
L_{f}=|A|+|B|+|C|+|D|+|E|,
$$

where $A$ - the total effect of regulation (according to the mathematical expectation); $B$ - the automatism function (by the mean square deviation, by the variational range and by the coefficient of variation); $C$ - vegetative homeostasis (according to a set of indicators: variational range, mode amplitude, regulatory system tension index); $D$ - stability of regulation (by coefficient of variation); $E$ - activity of the subcortical nerve centers (determined on the basis of the relative powers of the respiratory waves and waves of the first and second order with the allocation of states of pronounced and moderate increase in the activity of the subcortical nerve centers).

\section{Research results and discussion}

A model of the influence of traffic congestion on the fatigue level of a sanguine driver has been developed and has the following form [12]:

$$
L_{f c}=0.009 \cdot A_{d}+1.372 \cdot\left|\ln \left(\frac{D_{c}}{L_{f e}}\right)\right|+0.939 \cdot L_{f e},
$$

where $L_{f c}$ - fatigue level when exiting the congestion, c. u.; $A_{d}$ - driver's age, years; $D_{c}$ - duration of traffic congestion, $\min ; L_{f e}$ - fatigue level at the entrance to the congestion, c. u.

To study the effect of traffic congestions on the driver's fatigue level, graphs are constructed that generally reflect the influence of the initial state on the level of driver fatigue in the traffic congestion (Fig. 1-6).
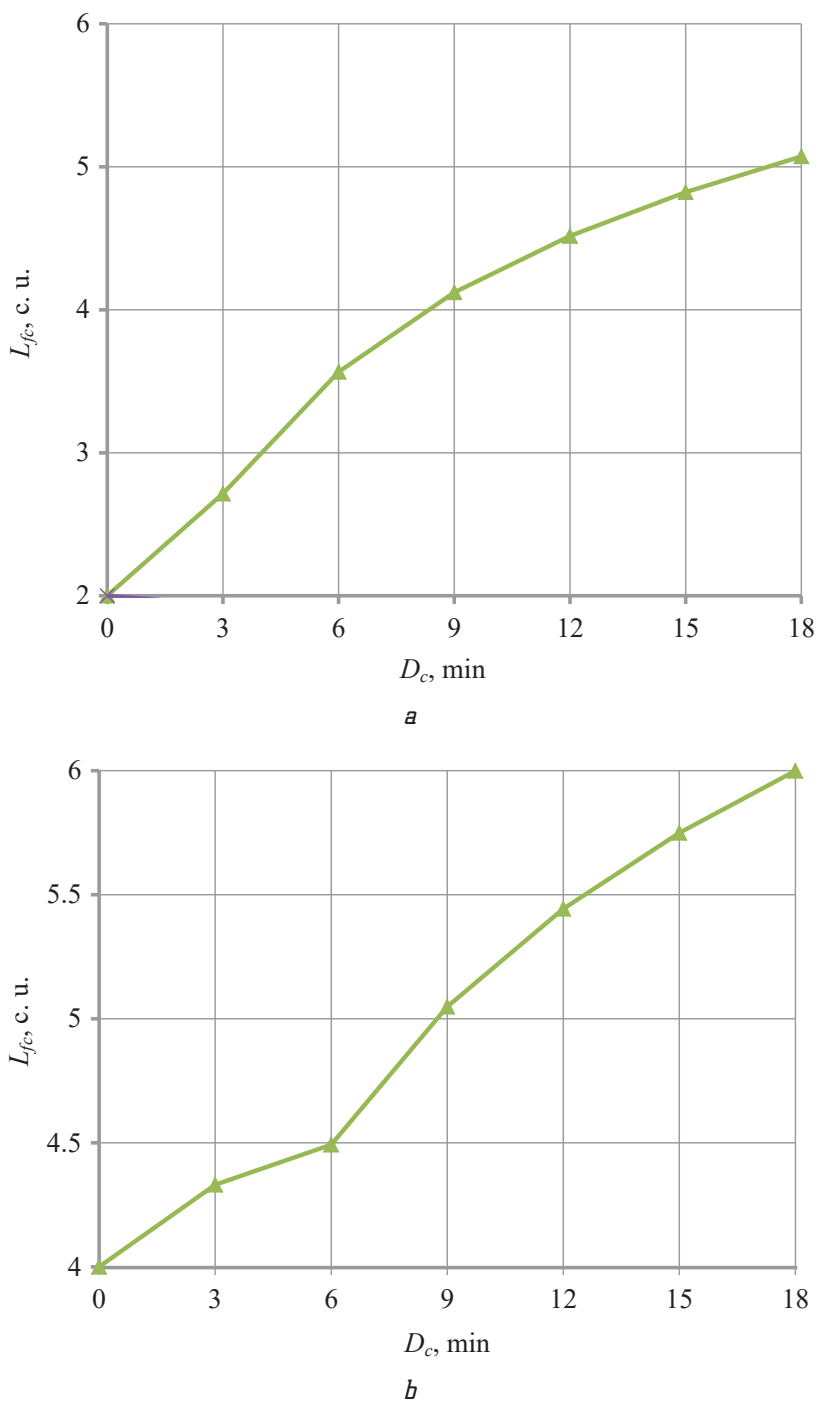

Fig. 1. The dependence of changes in the fatigue level of the 20 years-old sanguine driver in traffic congestion with: $a-L_{f e}=2$ c. u.; $b-L_{f e}=4$ c. u.

From Fig. 1, $a$ it is clear that the fatigue level of the sanguine driver at the end of the congestion rises and reaches 5 c. u., which reflects the state of pronounced tension of regulatory systems.

From Fig. 1, it is obvious that at the sixth minute of congestion, the fatigue level changes slightly, and then noticeably worsens, approaching the end of the traffic congestion to $6 \mathrm{c}$. $\mathrm{u}$.

The dynamics of changes in the state of young drivers of 20 years of traffic congestion at $L_{f e}=5$ c. u. and when $L_{f e}=6$ c. u. are presented in Fig. 2.

The state of the sanguine driver in Fig. 2, and at the beginning of the congestion it rises slightly due to inertial processes occurring in the body, and then its condition improves and returns to the original state - at 6 minutes of congestion. The improvement in the congestion is due to the fact that it entered the congestion in a stressed state. Further, its condition worsens significantly. In addition, the value of the fatigue level of the sanguine driver approaches 7 c. u., which indicates a pronounced overstrain of regulatory mechanisms.

In Fig. 2, the sanguine state improves by the sixth minute (by $8-10 \%$ ) and reaches less than the initial value. 
Then the situation changes, and the value of the fatigue level rises, exceeding at the end of the congestion $7 \mathrm{c}$. u. This indicates a gradual depletion of regulatory systems.

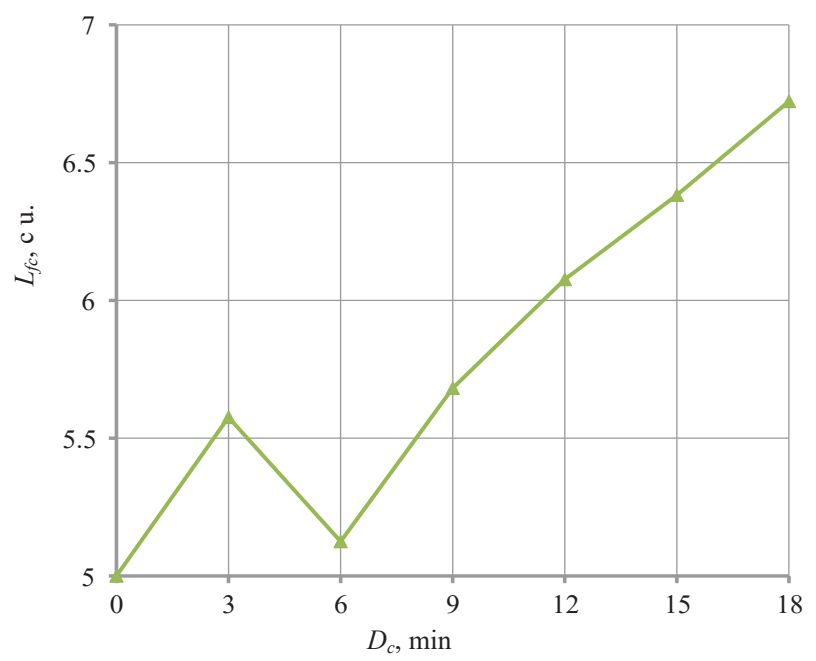

a

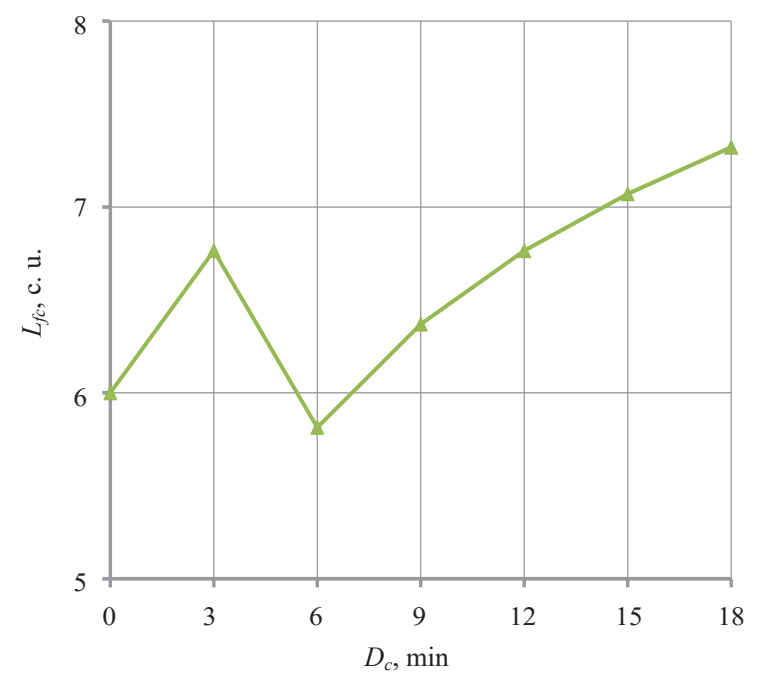

$b$

Fig. 2. The dependence of changes in the fatigue level of the 20 years-old sanguine driver in traffic congestion with: $a-L_{f e}=5$ с. u.; $b-L_{f e}=6$ c. u.

The change in the fatigue level of a 20 years-old sanguine driver in traffic congestion in three dimensions is shown in Fig. 3.

From Fig. 3 it is clear that with an increase in the initial fatigue level in the sanguine driver, the final fatigue level increases. The same trend is observed with an increase in the time spent by the driver in traffic congestion.

The state of the sanguine driver at high values of the initial fatigue level does not change until the 3rd minute of congestion. Further, its condition until the sixth minute of congestion is normalized, returning to the original. After the sixth minute of congestion, the fatigue level of the sanguine driver grows, approaching $8 \mathrm{c}$. u.

In a 60 years-old sanguine driver, the dynamics of a change in a functional state (Fig. 4, $a$ ) is similar to a change in a functional state shown in Fig. 1, $a$.

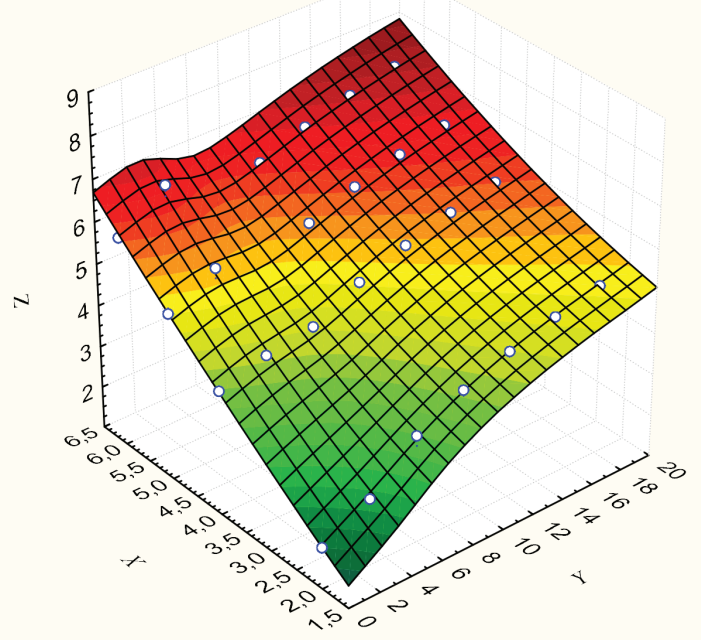

Fig. 3. Change in the final fatigue level $(Z)$ of the 20 years-old sanguine driver depending on entry level $(X)$ and congestion duration $(Y)$

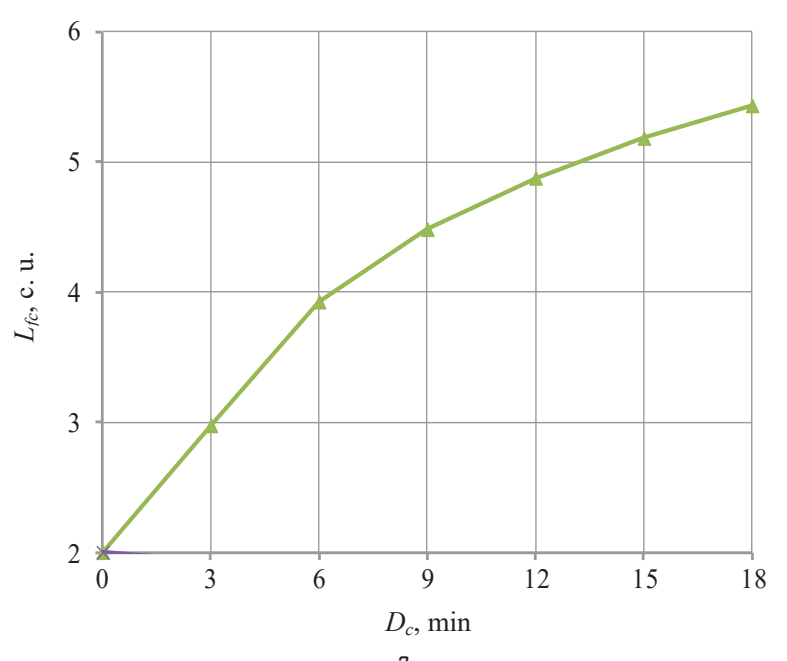

a

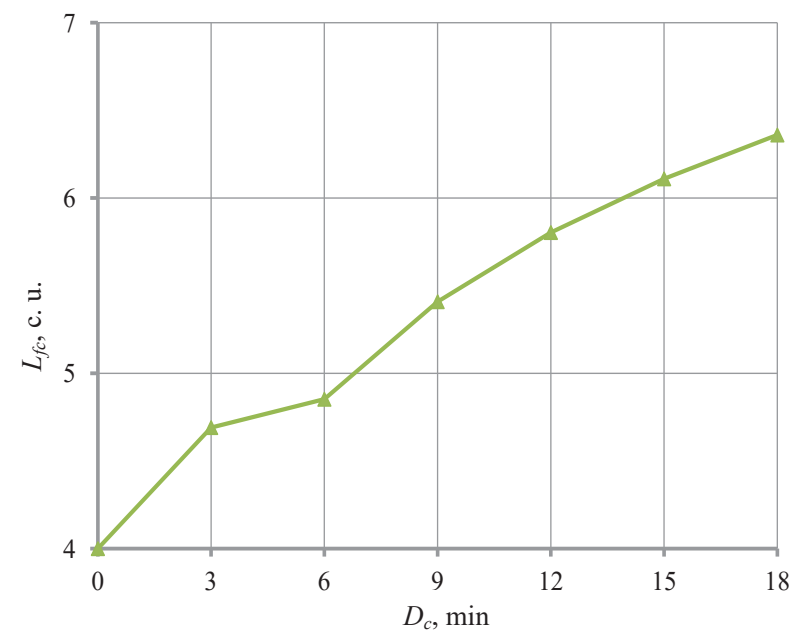

$b$

Fig. 4. The dependence of changes in the fatigue level of the 60 years-old sanguine driver in traffic congestion with: $a-L_{f e}=2$ c. u.; $b-L_{f e}=4$ c. u.

About the same situation with a change in the functional state of drivers, whose age is sixty years, in traffic congestion with an initial fatigue level equal to $4 \mathrm{c}$. u. (Fig. $4, b$ ). 
By the sixth minute of the mash, the fatigue level of the sanguine driver worsens more slowly than after that. Further, the value of the fatigue level of the sanguine driver grows significantly, approaching at the end of the congestion to 6.5 c. u.

The dynamics of the state of the 60 years-old sanguine driver in traffic congestion at $L_{f e}=5 \mathrm{c}$. u. and $L_{f e}=6 \mathrm{c}$. u. are presented in Fig. 5.
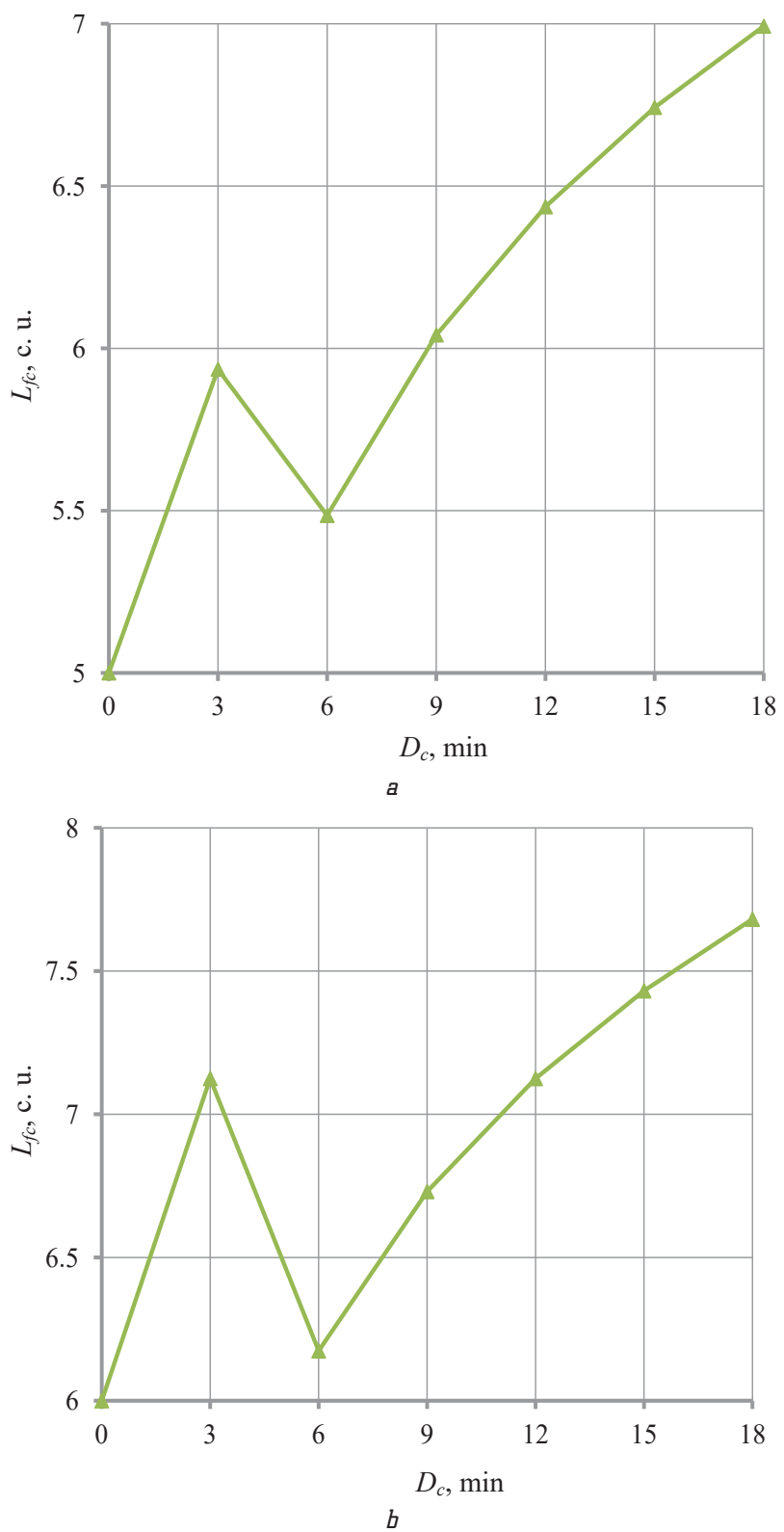

Fig. 5. The dependence of changes in the fatigue level of the 60 years-old sanguine driver in traffic congestion with:

$$
a-L_{f e}=5 \text { c. u.; } b-L_{f e}=6 \text { c. u. }
$$

The state of the sanguine driver (Fig. 5, $a$ ) at the beginning of the congestion increases slightly due to inertial processes occurring in the body, and then its condition improves in the sixth minute, without reaching, however, the initial values of the body's fatigue level. The improvement in the congestion is due to the fact that it entered the congestion in a stressed state. Further, its condition worsens significantly, and the value of $L_{f_{c}}$ at the end of the congestion in the sanguine driver is $7 \mathrm{c}$. $\mathrm{u}$.
In addition, the value of the fatigue level of the sanguine driver exceeds 7 c. u., which indicates a pronounced overstrain of regulatory mechanisms.

From Fig. 5, it is obvious that the condition of the sanguine driver improves by the sixth minute and reaches more than $7 \mathrm{c}$. u. Then the situation changes, and the fatigue level rises, approaching at the end of the congestion up to $8 \mathrm{c}$. u., which indicates a gradual depletion of regulatory systems.

The change in the fatigue level of a 60 years-old sanguine driver in traffic congestion in three dimensions depending on the initial level and congestion duration is shown in Fig. 6.

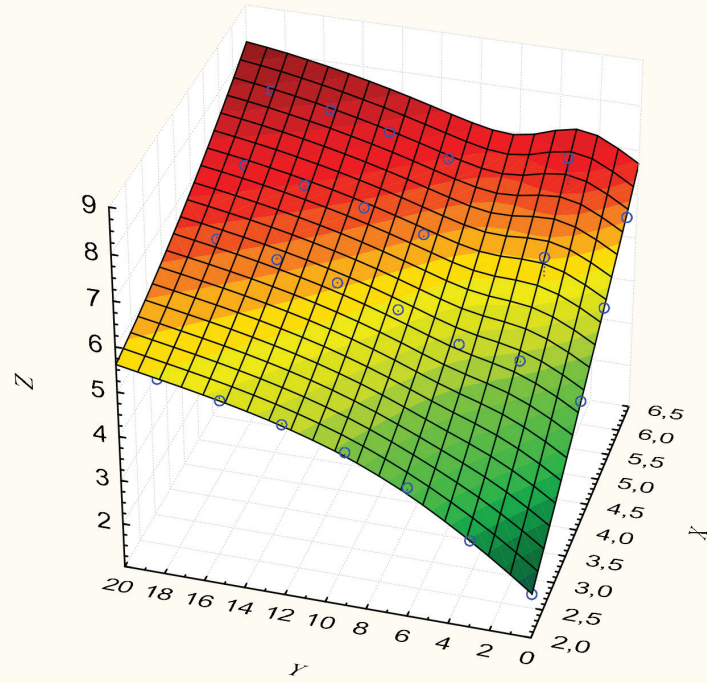

Fig. 6. Change in the final fatigue level $(Z)$ of the 60 years-old sanguine driver depending on entry level $(X)$ and congestion duration $(Y)$

From Fig. 6 it is clear that with an increase in the initial fatigue level, the sanguine driver increases its final level. The same trend is observed with an increase in the time spent by the driver in traffic.

The main results of the research are to determine the patterns of influence of traffic congestion parameters on a change in the functional state of a sanguine driver and on the final fatigue level in traffic congestion. The main factors affecting the fatigue level of the sanguine driver are: the value of the initial fatigue level of the driver before entering the traffic congestion, the duration of the traffic congestion and the age of the driver. The trends in the level of sanguine driver fatigue in traffic congestions identified during the study allow to predict the driver's behavior after exiting a traffic congestion and evaluate possible patterns of road traffic development that directly affect road safety.

\section{Conclusions}

A study of traffic congestion in the transport system of the city is conducted and patterns of their influence on the fatigue level of a sanguine driver are established. It has been established that if the condition of the sanguine driver of any age in front of the traffic congestion is normal, further stay in the traffic congestion leads to deterioration in its functional state. Analysis of the research results show that changes in the state of the 
sanguine driver in traffic congestion occur in different directions, depending on the value of the initial fatigue level before the start of the traffic congestion. If this value is more than five arbitrary units, then in the first minutes of congestion (up to about 2-4 minutes, depending on age), the driver's condition continues to deteriorate due to inertial processes in its body. Further, the fatigue level of the sanguine driver is reduced by 1-1.15 units (depending on age) within 3-4 minutes. Further stay in traffic negatively affects the driver's condition, increasing its fatigue level. The most significant negative impact of traffic congestion on the state of the sanguine driver is observed after the twelfth minute of traffic congestion. This may increase the likelihood of a traffic accident. The application of the laws obtained in the work will make it possible to evaluate and compare various variants of traffic management schemes in order to increase traffic safety.

\section{References}

1. Lobanov, E. M. (1980). Proektirovanie dorog i organizaciia doizheniia s uchetom psikhofiziologii voditelia. Moscow: Transport, 311.

2. Hiuliev, N. U. (2016). Liudskyi faktor i dorozhni zatory. Kharkiv: KhNUMH im. O. M. Beketova, 235.

3. Kundelekov, A. G. (2012). Vliianie transportnykh zatorov na psikhovegetativnii status voditelei obschestvennogo transporta $\mathrm{s}$ uchetom vozrasta i stazha raboty. Fundamentalnye issledovaniia, 12 (1), 82-85.

4. Zhang, L., Jia, Y., Niu, Z., Liao, C. (2014). Widespread Traffic Congestion Prediction for Urban Road Network Based on Synergetic Theory. Journal of Systems Science and Information, 2 (4), 366-371. doi: http://doi.org/10.1515/jssi-2014-0366

5. Yang, S. (2013). On feature selection for traffic congestion prediction. Transportation Research Part C: Emerging Technologies, 26, 160-169. doi: http://doi.org/10.1016/j.trc.2012.08.005

6. Qi, W., Pei, Y., Song, M., Bie, Y. (2013). Pattern Analysis of Driver's «Pressure-State-Response» in Traffic Congestion. Discrete Dynamics in Nature and Society, 6, 1-11. doi: http:// doi.org/10.1155/2013/853845
7. Son, S., Baek, Y. (2015). Design and Implementation of RealTime Vehicular Camera for Driver Assistance and Traffic Congestion Estimation. Sensors, 15 (8), 20204-20231. doi: http:// doi.org/10.3390/s150820204

8. Drum, D. K. (2014). Counteracting traffic congestion using intelligent driver feedback. doi: http://doi.org/10.32469/10355/44263

9. Lizbetin, J., Bartuska, L. (2017). The Influence of Human Factor on Congestion Formation on Urban Roads. Procedia Engineering, 187, 206-211. doi: http://doi.org/10.1016/ j.proeng.2017.04.366

10. Ito, T., Kaneyasu, R. (2017). Predicting traffic congestion using driver behavior. Procedia Computer Science, 112, 1288-1297. doi: http://doi.org/10.1016/j.procs.2017.08.090

11. Baevskii, P. M. (1979). Prognozirovanie sostoianii na grani normy i patologii. Moscow: Medicina, 298.

12. Giulev, N. U., Dolia, V. K. (2012). Nonlinear model of changes in functional state in driver sangvinnika traffic congestion. EasternEuropean Journal of Enterprise Technologies, 3 (4 (57)), 17-19 Available at: http://journals.uran.ua/eejet/article/view/4008

Gyulyev Nizami, Doctor of Technical Sciences, Associate Professor, Department of Transport Systems and Logistics, O. M. Beketov National University of Urban Economy in Kharkiv, Ukraine, e-mail:ngulev2@gmail.com, ORCID: http://orcid.org/0000-00025665-2978

Prasolenko Oleksii, PhD, Associate Professor, Department of Transport Systems and Logistics, O. M. Beketov National University of Urban Economy in Kharkiv, Ukraine, e-mail: prasolenko@gmail.com, ORCID: http://orcid.org/0000-0001-7248-9915

Litomin Eugene, Assistant, Department of Transport Systems and Logistics, O. M. Beketov National University of Urban Economy in Kharkiv, Ukraine, e-mail: prasolenko@gmail.com, ORCID: http:// orcid.org/0000-0003-1000-0832

Zinchenko Daria, Department of Transport Systems and Logistics, O. M. Beketov National University of Urban Economy in Kharkiv, Ukraine, ORCID: http://orcid.org/0000-0002-1419-3208 